\title{
A MORE SUBTLE SET OF INFORMATION IN CORPORATE ANNUAL REPORTS FOR DISADVANTAGED STAKEHOLDERS
}

\author{
Christo J Cronjé \\ School of Accounting Sciences, University of South Africa \\ Accepted February 2010
}

\begin{abstract}
The traditional corporate annual report consists of two types of disclosures, that is, mandatory and contextual disclosures. The research problem focuses on the issue whether full disclosure in corporate annual reports could entail mandatory and contextual disclosures as well as a more subtle set of information for disadvantaged stakeholders. To solve the research problem, use was mainly made of a literature review dealing with certain aspects of decision-useful financial reporting. The literature review was complemented by exploratory empirical research. It was found that full disclosure in corporate annual reports could consist of mandatory and contextual disclosures as well as a more subtle set of information for disadvantaged stakeholders.
\end{abstract}

Key words: Corporate annual reports, information needs of disadvantaged stakeholders, financial decision making

JEL M14

\section{1 \\ Introduction}

This article indicates that full disclosure in corporate annual reports entails both mandatory and discretionary disclosures (Gouws \& Cronjé, 2008; Stanton \& Stanton 2002: 479) as well as disclosures to enable or empower disadvantaged stakeholders with 'limited authority, ability, or resources' (Objective No. 2 in AICPA, 1973). Hence disclosures for a new stakeholder group emerge.

Information contained in our thoughts may be surveyed by a higher level of mental activity from which a more subtle level of information may emerge (Bohm \& Hiley, 1993: 385). This perspective shows that the original sets of information in corporate annual reports can be organised into a greater whole. Hence the information in corporate annual reports can be contextualised for the decision needs of disadvantaged stakeholders with limited authority, ability or resources in order to make the information more meaningful. In the process, other stakeholder groups could also benefit.

Corporate annual reports of entities produce two main types of information (Cronjé, 2008). The first type is mandatory information created by accounting practices such as International Financial Reporting Standards (IFRSs), International Accounting Standards (IASs) and JSE Ltd regulations. The second type of information disclosed is contextual information created by contextual accounting practices. Examples of contextual information are disclosure of environmental and social elements (IOD, 2009), disclosure of risks and strategies and disclosure of forward-looking information (IASB, 2009:10; Gouws \& Cronjé, 2008). The mandatory required information, such as the statement of financial position and notes, the statement of comprehensive income and notes and the statement of changes in equity and notes, in corporate annual reports, is contextualised by the contextual (sometimes referred to as voluntary or discretionary) disclosures (Gouws 
\& Cronjé, 2008). However, these contextual disclosures can still be expanded to cater for the disclosure requirements of disadvantaged stakeholders who include uninformed users with limited authority, ability or resources, resulting in economic inequalities.

\section{2}

\section{Research problem}

The research problem focuses on the issue whether full disclosure in corporate annual reports could entail mandatory and contextual disclosures as well as a more subtle set of information for disadvantaged stakeholders. In order to achieve this, this article will investigate certain aspects of decision-useful financial reporting, using mainly a review of current literature. The article will also be complemented by exploratory empirical research. Exploratory studies might have certain limitations, for example, they may not guarantee representativeness.

It was decided to elicit the viewpoints of the preparers of corporate annual reports regarding certain aspects of disclosures in corporate annual reports. A questionnaire was sent to listed companies, obtained on Excel from the JSE Ltd on 23 November 2006.

\section{3}

\section{Research method}

\subsection{The literature review}

The research is based mainly on a literature review dealing with the concept of the information needs of users in general. To ensure that reliable sources were incorporated, and as part of the inclusion criteria, use was made of South African journals, international journals, relevant books, articles, theses and dissertations. The reference lists of books and articles were used as a source for additional books and articles to be consulted. To find relevant articles, searches were mostly conducted via the electronic library (Oasis) of the University of South Africa (Unisa). Both manual and electronic searches were conducted, and primary and secondary sources were utilised. The following words were used for electronic sources: 'corporate annual reports', 'information needs' and 'financial decision making'.

\subsection{The questionnaire}

The literature review was complemented by empirical research in which a questionnaire for the preparers of corporate annual reports was sent to listed companies, using an Excel spreadsheet of listed groups of companies that was received via email from the JSE Ltd (dated 23 November 2006). A total of 45 responses were received, which equates to a response rate of 16.5 per cent. The questionnaires were sent via email. The purpose of the study was explained on the cover page and the questionnaire set out on the next page. The following sequence of events was used to prepare, send and analyse the responses to the questionnaires:

The statements in the questionnaire were evaluated on a five-point agreement Likert scale rating. The respondents were requested to indicate on a scale rating (S/D: strongly disagree; $\mathrm{D}$ : disagree; $\mathrm{U}$ : unsure; A: agree; S/A: strongly agree) to what extent they disagreed/agreed with each statement. The theme of the statements centred around the concept of financial decision making for the users of information in corporate annual reports.

The populations of the preparers of corporate annual reports were defined in terms of electronic mailing lists. Returned electronic responses/ questionnaires constituted convenience sampling. The database for preparers contains the email addresses of 357 groups of companies.

A generic message was compiled to direct the mail to the financial director of a company. Electronically returned questionnaire responses represented conveniently sampled preparers of corporate annual reports.

Table 1 provides a summary of the preparer responses. Thirty potential respondents out of a total population of 357 had no email addresses. Forty-five emails bounced back because the email addresses, as per the email list, did not exist. Ten companies indicated that they were unable to respond for various reasons (e.g. that they did not have the time or the resources to complete the questionnaire, or that it was not their policy to participate). Hence 272 responses could be expected. 
Table 1:

Summary of preparer responses

\begin{tabular}{|l|c|}
\hline Total population & 357 \\
\hline Less: Number of potential respondents with no email addresses on the JSE list & $(30)$ \\
\hline Emails that bounced back & $(45)$ \\
\hline Companies not prepared to respond & $(10)$ \\
\hline Anticipated number of responses & 272 \\
\hline
\end{tabular}

A total of 45 responses were received, which equates to a response rate of (45/272) or 16.5 per cent. The low response rate may not guarantee representativeness.

\section{4}

\section{Literature review}

There is a demand for accounting information because individuals wish to improve their investment decisions (IASB/FASB, 2008: 3; May \& Sundem, 1976: 763; Hooks \& Van Staden, 2004: 47) as well as their decisions regarding the allocation of scarce resources

(IASB/FASB, 2008: 3). An objective of financial reporting is to provide decision-useful information (IASB/FASB, 2008: 3; Stainbank \& Peebles, 2006: 69: Hooks \& Van Staden 2004: 46). The usefulness of information disclosed in corporate annual reports would be improved if it could benefit all users, including disadvantaged stakeholders in their financial decision making. Users need decision-useful information in order to interpret and make decisions about, inter alia, the growth opportunities of entities and the allocation of scarce resources. The financial statements required in terms of the statutes as well as the discretionary/contextualised disclosures in corporate annual reports form the basis of this information, and it could be argued that the decision-usefulness paradigm (relating to all disclosures in corporate annual reports, including contextual disclosures) encompasses the accountability paradigm (relating to only the financial statements required in terms of the statutes) (Gouws, 1997: $66 \&$ 68). The contextualisation of information in corporate annual reports would act as a guide for the disadvantaged stakeholders in their financial decision making. As a future-oriented concept, 'usefulness' seems to point to having meaning and insight into things that may be enjoyed and be of value to future users. It therefore governs the future behaviour of users.

The following aspects of decision-useful financial reporting are covered in the literature review: heterogeneous users; the credibility of mandatory disclosures; the credibility of discretionary disclosures; materiality; forwardlooking information; the average layperson; feedback from users; timeliness; management commentary; and the communication of accounting concepts.

\subsection{Heterogeneous users}

The decision makers involved in corporate annual reports are the various stakeholders. As far as statutory disclosures in corporate annual reports are concerned, the user groups are identified as present and potential equity investors, lenders and other creditors in making decisions in their capacity as capital providers (IASB/FASB, 2008). Information that is decision-useful to capital providers may also be useful to other users of financial reporting who are not capital providers (IASB/FASB, 2008: 1). As far as the contextual disclosures in corporate annual reports are concerned, the user groups also include, say, employees, lenders, customers, environmentalists and the public. Users have become heterogeneous (Cronjé, 2008: 236) and could include disadvantaged stakeholders who need to be empowered and informed.

\subsection{The credibility of mandatory disclosures}

Whether users consider the information in corporate annual reports to be credible 
will depend heavily on their view of the trustworthiness of the entity's management and auditors, and on the relevance of the information and the degree to which it faithfully represents the underlying economic phenomena (IASB/ FASB, 2008: 33). For financial information to be useful, it must possess two fundamental qualitative characteristics - relevance and faithful representation (IASB/FASB, 2008: 17). Information is relevant if it is capable of making a difference in the decisions made by capital providers. The information has to have predictive or confirmatory value, or both (IASB/FASB, 2008: 17). Verifiability is a quality of information that helps assure users that the information concerned faithfully represents the economic phenomena it purports to represent (IASB/FASB, 2008: 20). The statutory disclosures in corporate annual reports are relevant and verifiable because they are disclosed in accordance with the requirements of IFRSs and IASs and audited. The verifiability of contextual disclosures is more complex because some of these disclosures such as intellectual capital are not measurable. Although the verifiability of contextual disclosures is more complicated, they do fulfil a vital role in empowering and informing disadvantaged stakeholders in their decision making.

\subsection{The credibility of contextual disclosures}

Birken, Edwards and Woodland (2005: 193) refer to new tools and techniques of accounting that look outside the traditional boundaries of accounting, and which could form part of the contextual disclosures, for example, strategic management accounting (Kaizen, balanced scorecard and value chain analysis), corporate responsibility and ethical investments. The degree of credibility of contextual/discretionary disclosures in corporate annual reports is lower than that of the statutory disclosures (Cronjé, 2008: $208 \&$ 223) because they are only subjected to assurance reviews. However, these disclosures are of critical importance to disadvantaged stakeholders to guide them in their decision making and will better address their decisions than statutory disclosures only.

\subsection{Materiality}

Information is material if its omission or misstatement could influence the decisions that users make on the basis of an entity's financial information (IASB/FASB, 2008: 22). Hence corporate annual reports need to represent in all material respects all the information necessary for users to make proper decisions. According to FASB (1980), in Belkaoui (2004: 187), the characteristic used for the recognition of transactions and events is materiality. Events and transactions must therefore be material before they will be recognised. This characteristic applicable to the disclosure of statutory information as immaterial information will not necessarily be useful to decision makers. With regard to contextual disclosures, all information that will inform the disadvantaged stakeholders is important (Cronjé, 2008: 43).

From the above discussion it is clear that the attributes of statutory disclosures and contextual disclosures differ and meet the characteristics of the decision-useful approach to varying degrees. Although different in nature, the disclosures complement each other and give rise to full disclosure in corporate annual reports. Contextual disclosures can specifically be utilised to facilitate the decision-making needs of disadvantaged stakeholders.

\subsection{Forward-looking information}

The discussion paper on management commentary (MC) calls for information with an orientation towards the future, referred to as forward-looking information (IASB, 2009: 10). Preparers of corporate annual reports could therefore make use of the discretionary/ contextual section to report on this forwardlooking information, but need to take care not to speculate about future events and to report only on known future developments. While forwardlooking information is common in statutory disclosures in corporate annual reports, it appears more frequently as part of discretionary disclosures in corporate annual reports. Forward-looking information provides users of corporate annual reports with a sound basis on which to construct models for predicting future performance (EBR 360, 2004: 4). An abundance 
of information could still be disclosed in the corporate annual reports of entities. According to Beattie, McInnes and Fearnley (2002: 43), a comprehensive business reporting package should be developed (corporate annual reports could represent this comprehensive reporting package) to include an analysis by management of past performance (statutory disclosures and discretionary disclosures could provide this), as well as forward-looking information (discretionary disclosures). Information that would enable disadvantaged stakeholders to predict future performance would be most valuable. It is acknowledged that it would be difficult to express an audit opinion on this type of information.

\subsection{The average layperson}

To really understand information, disadvantaged stakeholders need to consult the contextual and mandatory disclosures in corporate annual reports. Corporate annual reports are not intended for the average layperson (Gouws \& Cronjé, 2001: 170). Disadvantaged stakeholders would probably not have the knowledge of the rules used in the preparation of disclosures in corporate annual reports and it would therefore be necessary to utilise quality contextual disclosures to bridge this gap to make disclosures meaningful for the stakeholders' decision making. Disadvantaged stakeholders would also have to make use of facilitators to guide them with relevant data. This would help them to grasp the big picture of an entity.

\subsection{Feedback from users}

For entities to provide decision-useful information, it would be necessary to obtain feedback from users via proper feedback systems, or users should negotiate with entities (AICPA 1994: 9) to give an indication of what types of information they need to disclose in corporate annual reports. To enhance corporate reporting, users should ideally give feedback, say, by completing questionnaires (that could be included in the corporate annual reports distributed to stakeholders) to indicate the type of decision-useful information they need. Where there is no opportunity to provide feedback, the usefulness of annual reports is in question (Clatworthy \& Jones, 1999: 43). It is essential to have an in-depth look at the primary driving force of disclosures in corporate annual reports. Statutory disclosures in corporate annual reports are driven by mandatory accounting practices, while contextual disclosures are a response to the feedback and needs of users for more contextual information. Corporate annual reports should provide for feedback from users. No opportunity currently exists for the disadvantaged stakeholders to provide feedback on the disclosures in corporate annual reports. Hence it would be necessary for the preparers of corporate annual reports to conduct research in order to disclose the required contextual information for their decision-making needs. The preparers need to perform research and negotiate with disadvantaged stakeholders on the types of information to be communicated because having the big picture depends on people deciding that they have the full picture (Hines, 1988: 253). The contextual section of the corporate annual report could be used to disclose this agreed-upon information.

\subsection{Timeliness}

Timeliness means having information available to decision makers before it loses its capacity to influence decisions (IASB/FASB, 2008: 21). Information not presented timeously loses its capacity to be relevant and to influence the decision-making process. Furthermore, providing information too quickly to users could result in a loss of faithful representation (IASB, 2008: 16). 'eXtensible Business Reporting Language' (XBRL) real-time business reporting is a probable solution to addressing timeliness. XBRL provides real-time business reporting, inter alia, through the Internet, which is instantly available for analysis. It involves tagging each individual item of data instead of treating information as a block of text. In the USA, companies are faced with extensive costs, inter alia, of complying with the requirements of the Sarbanes-Oxley Act (SOX) regarding corporate governance and transparency. These companies could in future focus on XBRL and the common platform it provides for business information. 
XBRL is set to become the standard way of recording, storing and transmitting business financial and discretionary information (OECD, 2006: 18).

The qualitative benefits of corporate reporting should justify the costs (IASB/FASB, 2008: 22) of extracting the information, but for disadvantaged stakeholders, this would be impossible to access. Contextual disclosures of the corporate annual report could be prepared more timeously than mandatory disclosures. Cronjé (2008: 125) argues that the reason for this is that mandatory disclosures must first be audited. However, to meet the requirements of the timeliness characteristic of decision usefulness, all disclosures in corporate annual reports need to be available as soon as possible. For the benefit of disadvantaged stakeholders, contextual disclosures could be disclosed on a more regular basis, and not only annually.

\subsection{Management commentary}

Management commentary (MC) provides a context in which to interpret an entity's financial position, financial performance and cash flows. It also provides an opportunity to understand management's objectives and its strategies for achieving those objectives (IASB, 2009: 4). $\mathrm{MC}$ encompasses reporting that is described in various jurisdictions as management's discussion and analysis (MD\&A), operating and financial review (OFR) or management's report (IASB, 2009: 7). The commentary to be given in the MC (IASB, 2009:9)

- provides management's view of the entity's performance, position and development

- supplements and complements the information presented in the financial statements

- has an orientation to the future

Table 2 below relates the five content elements to the needs of capital providers when using management commentary to assess an entity's performance and make financial decisions.

Table 2:

Content elements of a decision-useful management commentary

\begin{tabular}{|l|l|}
\hline \multicolumn{1}{|c|}{ Content elements } & \multicolumn{1}{|c|}{ User needs } \\
\hline Nature of the business & $\begin{array}{l}\text { The knowledge of the business in which an entity is engaged and } \\
\text { the external environment in which it operates. }\end{array}$ \\
\hline Objectives and strategies & $\begin{array}{l}\text { To access the strategies adopted by the entity and the likelihood } \\
\text { that those strategies will be successful in meeting management's } \\
\text { stated objectives. }\end{array}$ \\
\hline Resources, risks and relationships & $\begin{array}{l}\text { A basis for determining the resources available to the entity as } \\
\text { well as obligations to transfer resources to others; the ability } \\
\text { of the entity to generate long-term, sustainable net inflows of } \\
\text { resources; and the risks to which those resources-generating } \\
\text { activities are exposed, both in the near term and in the long } \\
\text { term. }\end{array}$ \\
\hline Results and prospects & $\begin{array}{l}\text { The ability to understand whether an entity has delivered results } \\
\text { in line with expectations and, implicitly, how well management } \\
\text { has understood the entity's market, executed its strategy and } \\
\text { managed the entity's resources, risks and relationships. }\end{array}$ \\
\hline Performance measures and indicators & $\begin{array}{l}\text { The ability to focus on the critical performance measures and } \\
\text { indicators that management uses to assess and manage the } \\
\text { entity's performance against stated objectives and strategies. }\end{array}$ \\
\hline
\end{tabular}


The MC is intended for use by an entity's existing and potential capital providers (IASB 2009: 8). Management commentary will, however, also play major roles in informing disadvantaged stakeholders because it describes the context in which an entity operates and will be more understandable to the disadvantaged stakeholders than only statutory disclosures.

\subsection{Communication of accounting concepts}

According to Belkaoui (1995: 41), the level of readability of accounting disclosures is troublesome. The variety and diversity of disadvantaged stakeholders with differences in culture, beliefs, education, perceptions, behaviour and so forth, complicates the task of preparers in providing information in corporate annual reports that will address their needs. A contextual dimension for disadvantaged stakeholders has to be added to corporate annual reports to make them more understandable for them.

The following aspects of accounting and corporate annual reports are discussed to demonstrate how they contribute to the communication of accounting concepts: the facilitation process of accounting; corporate annual reports as a necessary ingredient in decision making and the role of accounting in the enablement of disadvantaged stakeholders.

\subsubsection{The facilitation process of accounting}

Figure 1 illustrates the way in which accounting facilitates the process of financial decision making. It shows that accounting practices are the generators of accounting information, which is disclosed in corporate annual reports and which could be used to inform disadvantaged stakeholders.

Figure 1:

The facilitation process of accounting

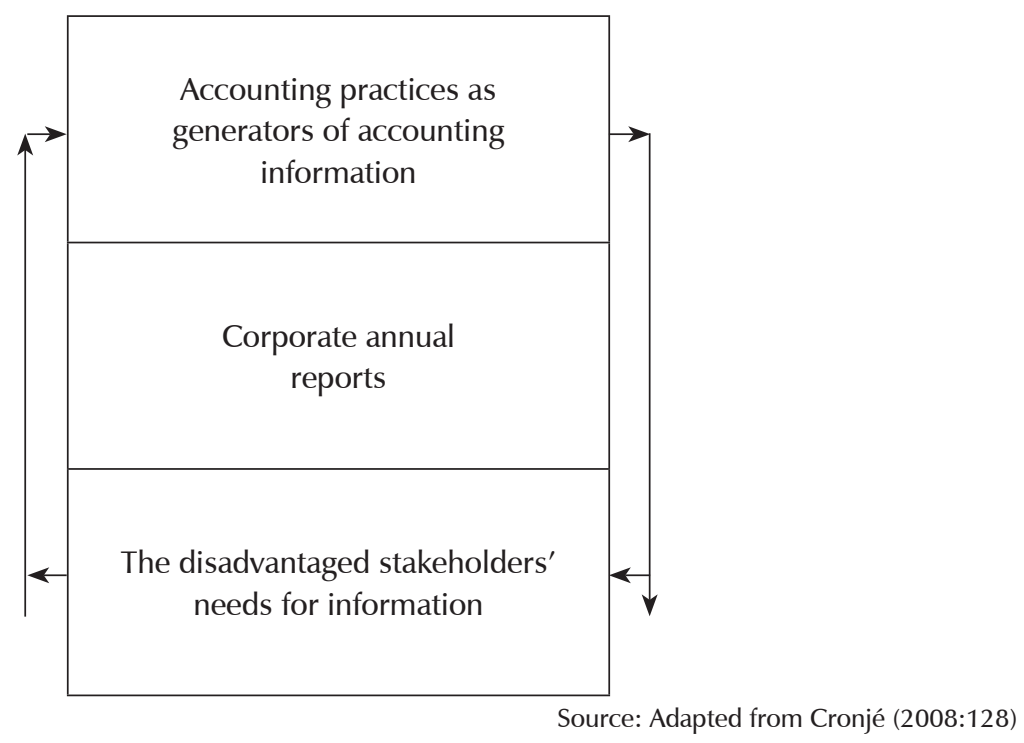

Accounting facilitates the process of financial decision making, because accounting practices as generators of accounting information react to the needs of users. Since one only observes the outcomes of accounting practices, the practices themselves are not so readily visible. The generators of the statutory information to be disclosed in corporate annual reports are the mandatory accounting practices, accounting postulates, assumptions, rules and praxes. The generators of the contextual information are the contextual accounting practices. The information product disclosed in corporate annual reports appears as a visible phenomenon. 
Users' needs influence the type of information to be disclosed in corporate annual reports. The needs of the disadvantaged stakeholders need to be researched in order to cater for their financial decision making. The accounting practices involved in producing this information are not important for the users (including the disadvantaged stakeholders), but the information product generated by these accounting practices is. This entire process is facilitated by accounting. Unfortunately, certain problems are experienced in the understanding of accounting disclosures. According to Belkaoui (1995: 41), the level of readability of accounting messages is troublesome and the level of understandability of the meaning of accounting imperfect. The reason for this is that the statutory disclosures in corporate annual reports are driven by mandatory accounting practices such as IFRSs and IASs, which because of their technicality, have little or no meaning for disadvantaged stakeholders. These disclosures need to be complemented by contextual disclosures (IASB, 2009: 4) and could increase the level of understandability and meaning for disadvantaged stakeholders.

The readability of contextual disclosures is less problematic, because the accounting messages can be explained more freely. These disclosures react to the feedback received from different stakeholders and appear, for example, in the form of ratios, graphs and common words and also in narrative and explanatory form (IASB, 2009: 10), which make them more user friendly than statutory disclosures. In order to cater for the information needs of the disadvantaged stakeholders, more use should be made of the contextual disclosures in corporate annual reports.

\subsubsection{Corporate annual reports as a necessary ingredient in decision making}

Corporate annual reports disclose two types of information, namely mandatory and contextual information. Traditionally, the financial statements (mandatory information) at the top of every analyst's list (Knutson, 1993: 16) have shown and are still showing outcomes only focusing entirely on the output of a system. Mandatory information seldom informs users on how the results were accomplished. According to Gouws and Lucouw (1999: 105), in the interpretation process it is necessary to disclose information about the various inputs and processes of the accounting and financial information presented because these will give an indication of the changes in forces, processes and capabilities that determine the numbers (outputs). Such disclosures, as currently required by the disclosure of management commentary (MC) (IASB, 2009), would give disadvantaged stakeholders a better understanding of the business of entities. The contextual section in corporate annual reports could be used to disclose more useful information about the inputs and processes that have produced outputs.

Corporate annual reporting is only an instrument in decision making if users utilise both sources of information, that is, both the statutory and discretionary disclosures of corporate annual reports. The mandatory information per se cannot provide all the information that would be useful to disadvantaged stakeholders because it only reports events and transactions that are measurable in accordance with the requirements of statutory accounting practices. The contextual disclosures fill the gap mandatory disclosures cannot provide (e.g. they report on intellectual capital, which is difficult to measure) in order to reflect the full picture. Research evidence suggests that discretionary narrative disclosures in annual reports are of great importance even for skilled users such as financial analysts, who are among the prime users of financial accounting information (Smith \& Taffler, 2000: 624). These contextual narrative disclosures will also be vital in empowering disadvantaged stakeholders with their information needs for decision making.

\subsubsection{The role of accounting in the enablement of disadvantaged stakeholders}

Entities in the modern age could adopt a culture of knowledge sharing (Von Krogh, Ichijo \& Nonaka, 2000: 262). As such the enablement of the disadvantaged stakeholders is of critical importance. This is confirmed by Cuganesan, Gibson and Petty (1997:433) who maintain that accounting has the potential to serve as an emancipator for the benefit of those people who 
are presently or potentially colonised, excluded, rendered invisible or exploited by the presently unchallenged operation of 'mainstream' accounting. The preparers of corporate annual reports need to emancipate disadvantaged stakeholders by delivering contextual disclosures for them. Mandatory disclosures only will not suffice. Because intelligence must be broadly distributed (Wheatley, 1999: 110), full disclosure in corporate annual reports is necessary.

Full disclosure encompasses statutory disclosures, discretionary/contextual disclosures and disclosures to enable/empower those with 'limited authority, ability, or resources' (Objective No. 2 in Trueblood (AICPA 1973); Wolk, Tearney \& Dodd, 2000: 184). One of the major roles that corporate annual reports have to play is the enablement and empowerment of disadvantaged stakeholders. Users need contextualised information from the corporate annual report for their specific financial decisions. According to Wolk et al. (2000: 318), the great complexity of business and financial and operating events means that financial statements have to be supplemented with an increasing array of disclosures. The disclosures in corporate annual reports can thus be contextualised for disadvantaged stakeholders in an effort to cater for their information needs in decision making.

The next section deals with the research findings of the questionnaires sent to preparers of corporate annual reports. In certain instances in the interpretation process, the categories 'strongly disagree' and 'disagree' as well as the categories 'agree' and 'strongly agree' were aggregated.

\section{5}

\section{Research findings from the questionnaire}

The research findings from the questionnaire are summarised in Table 2 below and cover the responses of preparers of corporate annual reports.

Table 2:

Responses of preparers of corporate annual reports $(n=45)$

\begin{tabular}{|c|c|c|c|c|c|c|}
\hline & \multicolumn{6}{|c|}{ Rating scale: percentage } \\
\hline & $\begin{array}{l}\text { Strongly } \\
\text { disagree }\end{array}$ & Disagree & Unsure & Agree & $\begin{array}{c}\text { Strongly } \\
\text { agree }\end{array}$ & Total \\
\hline $\begin{array}{l}\text { Statement 1: The objective of business } \\
\text { reporting in corporate annual reports has } \\
\text { moved away from a narrow approach } \\
\text { of accountability to a much wider } \\
\text { portrayal by providing information to } \\
\text { heterogeneous users for decision-making } \\
\text { purposes. }\end{array}$ & 2.2 & 4.5 & 8.9 & 64.4 & 20.0 & 100.0 \\
\hline $\begin{array}{l}\text { Statement 2: It is my view that corporate } \\
\text { annual reports provide credible statutory } \\
\text { information. }\end{array}$ & 0.0 & 4.5 & 0.0 & 73.3 & 22.2 & 100.0 \\
\hline $\begin{array}{l}\text { Statement 3: It is my view that } \\
\text { corporate annual reports provide credible } \\
\text { discretionary information. }\end{array}$ & 0.0 & 8.9 & 6.7 & 77.8 & 6.6 & 100.0 \\
\hline $\begin{array}{l}\text { Statement 4: The main objective of } \\
\text { corporate annual reports is to represent } \\
\text { in all material respects all the information } \\
\text { that is necessary for users to make proper } \\
\text { decisions. }\end{array}$ & 2.3 & 4.4 & 4.4 & 68.9 & 20.0 & 100.0 \\
\hline
\end{tabular}




\begin{tabular}{|l|l|l|l|l|l|l|}
\hline $\begin{array}{l}\text { Statement 5: Corporate annual reports } \\
\text { provide users with enough information } \\
\text { about future benefits for their decision } \\
\text { making. }\end{array}$ & 11.1 & 26.7 & 26.7 & 26.7 & 8.8 & 100.0 \\
\hline $\begin{array}{l}\text { Statement 6: Corporate annual reports } \\
\text { are not intended for the average } \\
\text { layperson. }\end{array}$ & 2.2 & 40.0 & 2.2 & 35.6 & 20.0 & 100.0 \\
\hline $\begin{array}{l}\text { Statement 7: Corporate annual reports } \\
\text { must also provide for feedback from } \\
\text { users. }\end{array}$ & 11.1 & 28.9 & 6.7 & 48.9 & 4.4 & 100.0 \\
\hline $\begin{array}{l}\text { Statement 8: It would be useful if } \\
\text { financial reporting could also be done } \\
\text { in digital form making use of 'eXtensible } \\
\text { Business Reporting Language' (XBRL). }\end{array}$ & 2.2 & 11.1 & 40.0 & 40.0 & 6.7 & 100.0 \\
\hline $\begin{array}{l}\text { Statement 9: An operating and financial } \\
\text { review (OFR), which captures the } \\
\text { whole story of entities' performance } \\
\text { and prospects through the eyes of } \\
\text { management, should be incorporated in } \\
\text { corporate annual reports. }\end{array}$ & 0.0 & 0.0 & 2.2 & 51.1 & 46.7 & 100.0 \\
\hline $\begin{array}{l}\text { Statement 10: To communicate } \\
\text { accounting concepts is a difficult task. }\end{array}$ & 0.0 & 24.4 & 6.7 & 53.3 & 15.6 & 100.0 \\
\hline
\end{tabular}

\subsection{Heterogeneous users}

Aggregation of the 'agree' and 'strongly agree' categories of statement 1 indicates that the majority (84.4 per cent) of the respondents agreed that the disclosure of information in corporate annual reports has moved away from an accountability paradigm to a paradigm in which the needs of heterogeneous users for decisionmaking purposes are eminent. Heterogeneous users would include disadvantaged stakeholders. Statutory disclosures mostly contain attributes of the accountability paradigm, while discretionary (contextual) disclosures generally contain attributes of the decision-usefulness paradigm. Preparers agree that corporate annual reports exist for decision-making purposes.

\subsection{The credibility of mandatory disclosures}

Statement 2 illustrates that the majority of respondents agreed with this statement. Of the respondents, 73.3 per cent agreed (while 22.2 per cent strongly agreed) that corporate annual reports provide credible statutory information. Statutory disclosures are more reliable and verifiable than contextual disclosures. Contextual disclosures that may be more relevant than reliable will play a vital role in empowering and informing disadvantaged stakeholders in their decision making.

\subsection{The credibility of contextual disclosures}

The level of assurance from the research results (statement 3 ) was lower than that from statutory information (statement 2). Statement 3 shows that 8.9 per cent of the respondents felt that the discretionary information of corporate annual reports is not at all credible compared to 4.5 per cent of the respondents as per statement 2, who indicated that the statutory information in corporate annual reports is not credible. Furthermore, only 6.6 per cent of the respondents strongly agreed that discretionary information is credible compared to 22.2 per cent who strongly agreed that statutory information is credible. The level of assurance in respect of discretionary disclosures is therefore lower than that for statutory disclosures. One respondent 
commented that 'the external auditors need to play a role in the verification of the discretionary information and need to play a bigger role by sitting in on management and board meetings'. The level of assurance for discretionary disclosures, however, was high (84.4 per cent of respondents agreed and strongly agreed) and one could therefore conclude that the discretionary disclosures of corporate annual reports are credible and contribute to disadvantaged stakeholders' information needs.

\subsection{Materiality}

Statement 4 shows that 88.9 per cent of the respondents agreed that corporate annual reports need to reflect in all material respects all the information for decision-making purposes. Preparers agreed that corporate annual reports should represent information that is necessary for users to make proper decisions. Materiality plays a key role as far as statutory disclosures in corporate annual reports are concerned. All information is important for contextual disclosures. Immaterial information that informs the disadvantaged stakeholders is meaningful.

\subsection{Forward-looking information}

Regarding statement 5, the respondents indicated a variety of opinions. The variety of opinions did not give a clear-cut indication about whether corporate annual reports provide users with enough information on future benefits for their decision making. However, the majority (37.8 per cent) disagreed, and one could therefore conclude that there is not enough information in corporate annual reports about future benefits for decision making. Forward-looking information relating to future benefits remains a key issue. Discretionary (contextual) disclosures should include forward-looking information relating to future benefits for disadvantaged stakeholders, say, as part of the management commentary (MC). Corporate annual reports should provide decision-useful information that could enable disadvantaged stakeholders with information to predict future prospects. To enable disadvantaged stakeholders to make predictions, forward-looking information should form part of contextual disclosures.

\subsection{The average layperson}

Users must play an active role in extracting the information they need. The majority of respondents (55.6 per cent) agreed with statement 6 . Although corporate annual reports are knowledge-sharing documents, users (disadvantaged stakeholders) need to develop some skill in extracting the information they require because corporate annual reports are not for the average layperson. Alternatively, a facilitator could be used to provide disadvantaged stakeholders with the relevant information.

\subsection{Feedback from users}

The majority (53.3 per cent) of respondents were in favour of the idea that corporate annual reports must also provide for feedback from users. Currently, there are virtually no processes in place to take care of feedback from users, particularly disadvantaged stakeholders. The feedback on the statutory disclosures needs to be channelled back to the preparers of corporate annual reports, and ultimately to standard setters. Feedback on the discretionary disclosures needs to be channelled back to the preparers of corporate annual reports and ultimately to bodies such as the Global Reporting Initiative (GRI) and the South African Institute of Chartered Accountants (SAICA). Preparers of corporate annual reports need to conduct research in order to disclose the required contextual information for the decision-making needs of disadvantaged stakeholders.

\subsection{Timeliness}

Statement 8 shows that there is currently still great uncertainty about the usefulness of XBRL. Of the respondents, 40 per cent were uncertain about the usefulness of XBRL, while 46.7 per cent were of the opinion that it is indeed useful. Of the respondents, 40 per cent indicated that they were unsure whether XBRL would be useful. Is this a reflection of the fact that they were unaware of XBRL, or a belief that the cost of implementation would outweigh its benefits? Because financial and other business information needs to be available sooner and faster if companies wish to compete for capital 
and investor attention, the benefits of adopting XBRL should be clear. For the benefit of disadvantaged stakeholders, using XBRL, contextual disclosures could be disseminated on a timelier basis.

\subsection{Management commentary}

The results of statement 9 clearly indicate that most of the respondents were in favour of the OFR, which is the equivalent of the information disclosed in the MC. This could be introduced as part of the contextual disclosures of corporate annual reports as a separate section to be identified as the $\mathrm{MC}$, and would definitely also be of assistance regarding the information needs of disadvantaged stakeholders.

\subsection{Communication of accounting concepts}

Statement 10 shows that the majority of respondents were aware of this difficulty. One of the respondents added the comment: 'especially with the introduction of IFRS'. The research results indicate that 68.9 per cent of the respondents were aware that the communication of accounting concepts is a difficult task. The communication of accounting concepts and numbers to disadvantaged stakeholders with different levels of understanding of accounting phenomena and different objectives remains a difficult task.

The above research results as a whole show that preparers of corporate annual reports support the importance of distinguishing between statutory and contextual disclosures and the different roles they fulfil in providing decision-useful information to heterogeneous users.

\section{6}

\section{Conclusion}

The primary driving force in an information product like corporate annual reports is the users' need for decision-useful information to optimise returns and reduce uncertainty. The corporate annual reports of companies therefore disclose two types of information. The first type is mandatory information (e.g. the statement of financial position and notes, the statement of comprehensive income and notes as well as the statement of changes in equity and notes). The second type is contextual information (e.g. the disclosure of environmental and social elements, disclosure of risks, strategies and forward-looking information). Full disclosure in corporate annual reports includes disclosures that would enable/empower users with 'limited authority, ability, or resources' (Objective No. 2 in AICPA, 1973). Hence corporate annual reports should also address the information needs of disadvantaged stakeholders by producing a more subtle level of information. The contextual disclosures of corporate annual reports could be used to cater for the disclosure requirements of the disadvantaged stakeholders as well. The research problem focused on the issue whether the information in corporate annual reports is meant only for the informed or also for disadvantaged stakeholders.

The article started with a literature review to investigate the needs of disadvantaged stakeholders for decision-making purposes, and the following factors were addressed: heterogeneous users; the credibility of mandatory disclosures; the credibility of contextual disclosures; materiality; forward-looking information; the average layperson; feedback from users; timeliness; management commentary; and the communication of accounting concepts, which included the facilitation process of accounting; corporate annual reports as a necessary ingredient in decision making; and the role of accounting in the enablement of disadvantaged stakeholders.

For the purpose of an exploratory study it was decided to elicit the viewpoints of preparers of corporate annual reports by distributing questionnaires. The research results as a whole showed that preparers of corporate annual reports support the importance of distinguishing between statutory disclosures and contextual disclosures and the different roles they play in providing decision-useful information to heterogeneous users.

The conclusion is that statutory disclosures are only a subset of the disclosures (Gouws \& Cronjé, 2008: 118) that entities release and that the contextual disclosures could play a key 
role in the empowerment of disadvantaged stakeholders. For entities to provide decisionuseful information, it is necessary to obtain feedback from disadvantaged stakeholders via proper feedback systems (e.g. questionnaires provided as part of corporate annual reports to be completed and returned by disadvantaged stakeholders), or users (including disadvantaged stakeholders) should negotiate with entities (AICPA, 1994: 9) to give an indication of what types of information should be disclosed in corporate annual reports. Feedback could result in seismic shifts in the disclosures in corporate annual reports. It would be necessary to distinguish between the information required and nonessential information (AICPA, 1994: 11). Nonessential information would only increase the cost of corporate annual reports to entities. Decision-useful information should be limited to what is essential for decision making and should take the needs of the disadvantaged stakeholders into account.

For future research, the responses of disadvantaged stakeholders should be obtained to elaborate on the kinds of information they would like to see as part of contextual disclosures in corporate annual reports.

\section{References}

AICPA, vide American Institute of Certified Public Accountants.

AMERICAN INSTITUTE OF CERTIFIED PUBLIC ACCOUNTANTS. 1973. The Trueblood report: objectives of financial statements, New York: The Institute.

AMERICAN INSTITUTE OF CERTIFIED

PUBLIC ACCOUNTANTS. Special Committee on

Financial Reporting. 1994. Improving business reporting

- a customer focus: meeting the information needs of investors and creditors: a comprehensive report of the Special Committee on Financial Reporting, American Institute of Certified Public Accountants (Jenkins Committee Report). New York: The Institute.

BEATTIE, V., MCINNES, B. \& FEARNLEY, S. 2002.

Financial reporting through the eyes of management.

Accounting and Business, 5(10): 43-44.

BELKAOUI, A. 1995. The linguistic shaping of accounting, Westport, Conn.: Quorum Books. BELKAOUI, A. 2004. Accounting theory. ( $5^{\text {th }}$ ed.) London: International Thomson Business.
BIRKEN, F., EDWARDS, P. \& WOODWARD, D.

2005. Accounting's contribution to a conscious cultural evolution: an end to sustainable development. Critical Perspectives on Accounting, 16(3): 185-208. BOHM, D. \& HILEY, B.J. 1993. The undivided universe: an ontological interpretation of quantum theory, London \& New York: Routledge.

CLATWORTHY, M. \& JONES, M. 1999. Annual reporting: room for improvement? Management Accounting, (UK) 77(4): 43-44.

CRONJÉ, C. 2008. Corporate annual reports (CARS): accounting practices in transition, Saarbrücken, Germany: VDM Verlag Dr. Müller.

CUGANESAN, S., GIBSON, R. \& PETTY, R.

1997. Exploring accounting education's enabling possibilities: an analysis of a management accounting text. Accounting, Auditing and Accountability Journal, 10(3): 432-453.

EBR 360, vide Enhanced Business Reporting Consortium. ENHANCED BUSINESS REPORTING

CONSORTIUM. 2004. Report of the private company task force to the special committee on enhanced business reporting - USA. [Online]. Available:http://www. ebr360.org. Accessed: 26 March 2008.

FASB, vide International Accounting Standards Board and Financial Accounting Standards Board.

GOUWS, D.G. 1997. Perspectives surrounding accounting communication. Meditari Accountancy Research, 18(34): 61-82.

GOUWS, D.G. \& LUCOUW, P. 1999. The process beyond the numbers and ratios. Meditari Accountancy Research, 7: 99-122.

GOUWS, D.G. \& CRONJÉ, C.J. 2001. The influence of full compliance with the Companies Act on the knowledge-creating potential of the directors' report. Meditari Accountancy Research, 9: 155-173.

GOUWS, D.G. \& CRONJÉ, C.J. 2008. Corporate annual reports: accounting practices in transition. Southern African Business Review, 12(2): 108-133. HINES, R.D. 1988. Financial accounting: in communicating reality, we construct reality. Accounting, Organizations and Society 13(3): 251-261. HOOKS, J. \& VAN STADEN, C. 2004. Preparers' perceptions of the decision usefulness of FRS15. Qualitative Research in Accounting and Management, 1(1): 46-65.

IASB, vide International Accounting Standards Board. INSTITUTE OF DIRECTORS IN SOUTHERN AFRICA. 2009. King report on governance for South Africa, Johannesburg.

INTERNATIONAL ACCOUNTING STANDARDS BOARD. 2008. Information for observers. Exposure draft: an improved conceptual framework. Comment letter summary: objectives and qualitative characteristics, London. 
INTERNATIONAL ACCOUNTING STANDARDS BOARD. 2009. Exposure draft: management commentary (MC), London.

INTERNATIONAL ACCOUNTING STANDARDS BOARD AND FINANCIAL ACCOUNTING STANDARDS BOARD. 2008. Exposure draft: conceptual framework for financial reporting, London \& Norwalk, Conn.

IOD, vide Institute of Directors in Southern Africa. KNUTSON, P.H. 1993. Financial reporting in the 1990s and beyond: a position paper, Charlottesville, VA: Association for Investment Management and Research.

MAY, R.G. \& SUNDEM, G.L. 1976. Research for accounting policy: an overview. Accounting Review, 51(4): 747-763.

OECD, vide Organisation for Economic Cooperation and Development.

ORGANISATION FOR ECONOMIC

COOPERATION AND DEVELOPMENT, CORPORATE AFFAIRS DIVISION, Directorate for Financial and Enterprise Affairs. 2006. Intellectual assets and value creation: implications for corporate reporting, Paris. [Online] Available: http://www. oecd.org/dataoecd/2/40/37811196.pdf. Accessed: 7 September 2007.

SMITH, M. \& TAFFLER, R.J. 2000. The chairman's statement: a content analysis of discretionary narrative disclosures. Accounting, Auditing and Accountability Journal, 13(5): 624-646.

STAINBANK, L. \& PEEBLES, C. 2006. The usefulness of corporate annual reports in South Africa: perceptions of preparers and users. Meditari Accountancy Research, 14(1): 69-80.

STANTON, P. \& STANTON, J. 2002. Corporate annual reports: research perspectives used. Accounting, Auditing and Accountability Journal, 15(4): 478-500.

VON KROGH, G., ICHIJO, K. \& NONAKA, I. 2000. Enabling knowledge creation: how to unlock the mystery of tacit knowledge and release the power of innovation, New York: Oxford University Press.

WHEATLEY, M.J. 1999. Leadership and the new science: discovering order in a chaotic world, $\left(2^{\text {nd }} \mathrm{ed}.\right)$

San Francisco, Calif.: Berrett-Koehler. WOLK, H.I., TEARNEY, M.G. \& DODD, J.L. 2000. Accounting theory: a conceptual and institutional approach, $\left(5^{\text {th }}\right.$ ed.) Cincinnati, Ohio: South-Western College. 